\author{
Vitaly Boiko
}

\title{
POLYMERIZATION OF ISOPRENE IN ETHYLACETATE IN THE PRESENCE OF HYDROGEN PEROXIDE
}

\author{
Institute of M acromolecular Chemistry of National Academy of Sciences of Ukraine \\ 48, Kharkivske Sh., 02160 K yiv, Ukraine \\ boikovita@bigmir.net
}

Received: J uly 01, 2009

(C) Boiko V., 2010

\begin{abstract}
Orders by monomer and initiator at polymerization of isoprene in solution of ethylacetate under the action of hydrogen peroxide have been determined. The order by monomer is equal to $1.49 \pm 0.03$, by initiator $-0.46 \pm 0.05$. Unlike polymerization in solution of isopropyl alcohol, a process in ethylacetate proceeds in homogeneous solution. The value of order by monomer differs from the one for ideal polymerization, pointing to the specific mechanism of polymerization in the given system, while the value of order by initiator points to the quadratic termination of macroradicals, typical for ideal polymerization. These data as well as the literature lead to the conclusion that initiation takes place through decomposition of monomer-initiator complex.
\end{abstract}

Keywords: polymerization, order of reaction, isoprene, influence of solvent, hydrogen peroxide, ethylacetate, complex formation.

\section{Introduction}

Understanding the influence of solvent used in radical polymerization in the course of time changed from the complete ignoring to the recognition of its role as an agent of chain transfer, further as medium, in which the decomposition of initiator and reactions of primary radicals in a cage take place, then as an agent that affects the process of polymerization by selective solvation of monomers and by intermolecular donor and acceptor interaction with monomers $[1-5]$. The last data $[6,7]$ testify that in some systems solvent can be a competent participant of chemical transformations, which take place in the polymerization system. These features of the solvent influence evidently show up at the use of hydrogen peroxide (HP) as initiator [6-8]. This initiator is highly susceptible to the formation of hydrogen bonds owing to the presence of both electron donating oxygen atoms and electron accepting hydrogen atoms [9]. Hydroxyl radicals from HP are not only added to monomer with initiation of polymerization but also are very active agents in the reactions of the abstraction of hydrogen atom from various substrates (with formation of water that favors to this reaction in an enthalpy contribution [10]). The study of the diene polymerization under the action of HP showed considerable influence of solvent on the yields of oligodienes and their properties [6, $7,11,12]$. These results had led the authors $[12,13]$ to the assumption about the direct participation of solvent in the act of the HP decomposition, and later it was shown [7] that fragments of alcohols incorporate into oligomers. The influence of solvent on the phase state of the system was also found out. Namely by running polymerization in the biphasic system, where oligomer is separated as microdroplets of emulsion, we explained the anomalous values of reaction orders by monomer and initiator [14]. For more enhanced understanding this influence, it seems important to conduct polymerization in solvent, in which both oligomer and monomer are soluble, so that the system remains one-phase at all conversions of monomer. Ethylacetate is such solvent.

\section{Experimental}

\subsection{M aterials}

Isoprene from Merck with contents of basic matter $>98 \%$ was distilled before filling dilatometers; the fraction 307.2-307.3 K was drawn. Isopropyl alcohol (IPA) (Merck) with purity of $99.8 \%$ was also used freshly distilled. HP (produced in France) with contents of basic matter $50 \mathrm{wt} \%$ was used as received. Ethylacetate (EA) (produced in Russia) was cleaned from ethanol by treatment with soda and calcium chloride $[15, \mathrm{p} .605]$ and distilled directly before usage. Such preparation of reagents turned out to be sufficient, as good reproducibility of the experiments showed. 


\subsection{Preparation and Execution of Polymerization}

Polymerization was conducted in ampoules of Pyrex glass with an inner diameter of $8-10 \mathrm{~mm}$. The ampoules were specially prepared for polymerization to exclude the influence of wall material on the HP decomposition [14]. The absence of oxygen bubbles on the walls of the ampoules after wetting them in concentrated HP served as a criterion of fitness. The release of the contents of the ampoules from oxygen was fulfilled by the standard technique of freezing - evacuating - thawing [12] and sealing under vacuum. Kinetics of polymerization was measured by a dilatometric method by means of cathetometer KM- 6 with the scale division of $0.01 \mathrm{~mm}$. The process was conducted at $363 \pm 0.1 \mathrm{~K}$ in a water thermostat.

The orders of polymerization reactions were measured by a standard method from dependence of initial rates on concentration of monomer (initiator) in double logarithmic coordinates.

\section{Results and Discussion}

The dependence of isoprene conversion and initial velocity of polymerization in the mixed solvent IPA-EA from a molar ratio of IPA to HP is represented in Fig. 1. As can be seen, initial velocity of polymerization increases quickly with increase of IPA contents in mixed solvent.

The sigmoid type of the curve in the mixed solvent evidently demonstrates the strong influence of solvent on the polymerization rate. Maximal growth of speed is observed at an IPA volume contents of $15 \%$ (18 mol \%) and already at IPA contents of $35 \%$ initial velocity and yield achieve the values of clean IPA. This influence can be explained by different polarities of solvents: dielectric permeabilities are 6.0 and 18.3 for EA and IPA accordingly. Besides, IPA is considerably more susceptible to formation

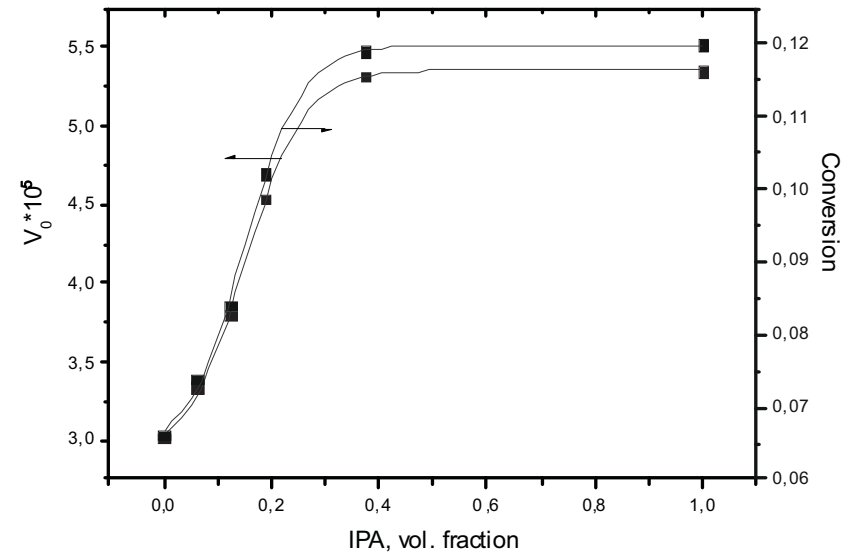

Fig. 1. Dependence of the isoprene conversion and the polymerization initial rate in the mixed solvent isopropyl alcohol-ethylacetate on the content of isopropyl alcohol.

Concentrations (mol/l): isoprene $-4.00, \mathrm{HP}-0.927$.

Temperature is $363 \mathrm{~K}$, time period is $2.5 \mathrm{~h}$

of hydrogen bond than EA. The indexes of capacity for the hydrogen bond formation as a donor of hydrogen are 0.76 and 0.00 while as an acceptor of hydrogen they make up 0.84 and 0.45 for IPA and EA accordingly [16]. Another important influence factor is the presence of the week $\mathrm{C}$ $\mathrm{H}$ bond in IPA $\alpha$-carbon atom, which is $382 \mathrm{~kJ} / \mathrm{mol}$ compared to 392 in ethyl alcohol and 388 in other primary alcohols [17].

The curve of the monomer conversion goes simbatically to the initial velocity curve, demonstrating the same character of dependence on the solvent composition.

The most complete information about the mechanism of polymerization can be derived from the values of the reaction orders by monomer and initiator. On Fig. 2 and 3 and in Table 2 and 3 the corresponding results are presented.

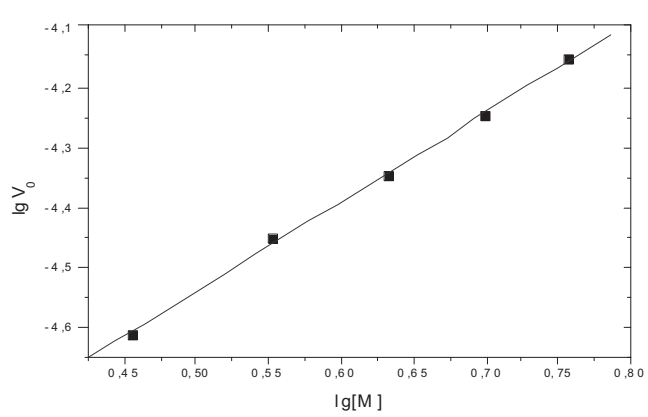

b

Fig. 2. The order by monomer in ethylacetate solution: kinetic curves of polymerization (a) and initial rate - monomer concentration dependence (b); concentration of HP is $0.741 \mathrm{~mol}$; concentrations of isoprene (mol/l) are 5.71 (1), 5.00 (2), $4.28(3), 3.57(4)$ and $2.86(5)$ 
The order by monomer value in EA is close to 1.5. In the literature this case is explained by participation of monomer in initiation of polymerization [5, p. 168]. Taking into account complications which arise at the explanation of the formation of a solvent-initiator complex [13] in the studied system, we are inclined to the conclusion that in this case a complex between $\pi$-bonds of diene monomer and a hydrogen atom of HP is created. Earlier [14] we pointed to the fact that present literature data on polymerization with HP do not allow to choose some certain viewpoint concerning to the mechanism of initiation in such systems. For example, a supposition was made about the presence of the zones with different local concentrations of components, in which one or another component (monomer, initiator) prevails [18].
The polymodal character of the molecular mass distribution of oligobutadienes testified to that. In our study similar polymodality was not observed. In the given system 1.5 order by monomer points to the stochiometric interaction of components of the system in favor of the formation of the isoprene-HP complex.

The order by initiator corresponds to the case of ideal radical polymerization, when the quadratic termination of macroradicals takes place. At the absence of a separate phase of oligomer, as at polymerization in IPA solution [14], there are no reasons for the deviation from the ordinary termination of macroradicals, which is carried out for dienes by their recombination.

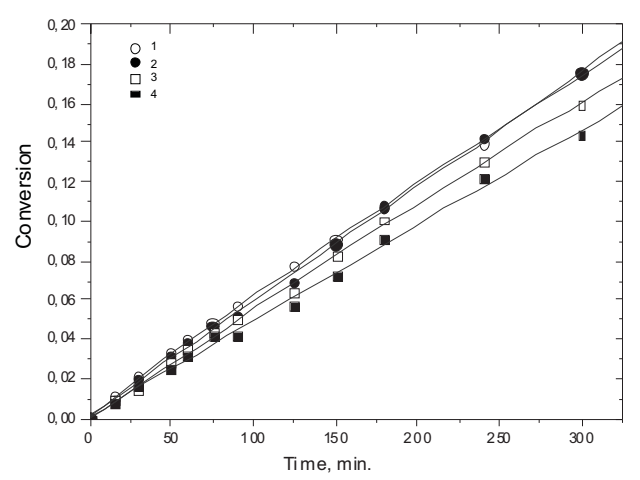

a

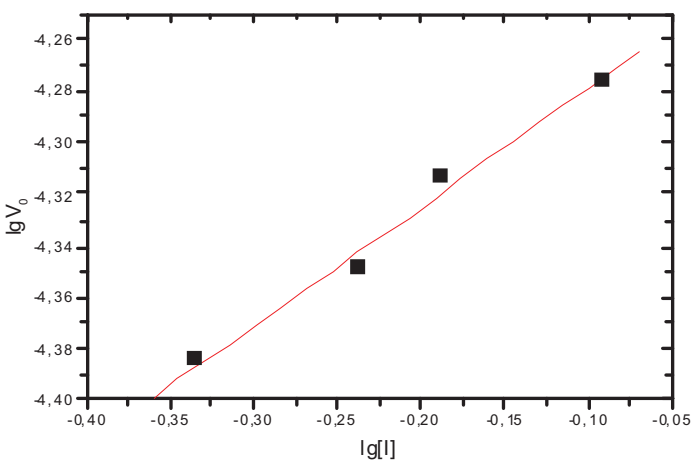

b

Fig. 3. The order by initiator in ethylacetate solution: kinetic curves of polymerizations (a) and initial rate - initiator concentration dependence (b); concentration of isoprene is $4.66 \mathrm{~mol} / \mathrm{l}$; concentrations of $\mathrm{HP}(\mathrm{mol} / \mathrm{l})$ are 0.807 (1), 0.649 (2),

$0.577(3)$ and $0.461(4)$

Table 1

The order by monomer (isoprene) in the polymerization reaction in ethylacetate solution

\begin{tabular}{|c|c|c|c|c|}
\hline $\begin{array}{c}\text { Monomer concentration }[\mathrm{M}], \\
\mathrm{mol} / 1\end{array}$ & $\lg [\mathrm{M}]$ & $\begin{array}{c}\text { Initial rate, } \mathrm{v}_{0} \cdot 10^{5}, \\
\mathrm{~mol} \mathrm{l}^{-1} \mathrm{~s}^{-1}\end{array}$ & $\operatorname{lg~\mathrm {v}_{0}}$ & Order \\
\hline 5.71 & 0.757 & 7.00 & -4.16 & $1.49 \pm 0.03$ \\
5.00 & 0.699 & 5.64 & -4.25 & \\
4.28 & 0.632 & 4.49 & -4.35 & \\
3.57 & 0.553 & 3.52 & -4.45 & \\
2.86 & 0.456 & 2.46 & -4.61 & \\
\hline
\end{tabular}

Note: initiator (HP) concentration is $0.741 \mathrm{~mol} / 1$

Order by initiator (hydrogen peroxide) in the isoprene polymerization reaction in ethylacetate solution

\begin{tabular}{|c|c|c|c|c|}
\hline $\begin{array}{c}\text { Initiator concentration }[\mathrm{I}], \\
\mathrm{mol} / 1\end{array}$ & $\lg [\mathrm{I}]$ & $\begin{array}{c}\text { Initial rate, } \mathrm{v}_{0} \cdot 10^{5}, \\
\mathrm{~mol}^{-1} \mathrm{~s}^{-1}\end{array}$ & $\lg \mathrm{v}_{0}$ & Order \\
\hline 0.807 & -0.093 & 5.31 & -4.275 & $0.46 \pm 0.05$ \\
0.649 & -0.188 & 4.85 & -4.314 & \\
0.577 & -0.239 & 4.43 & -4.354 & \\
0.461 & -0.336 & 4.13 & -4.384 & \\
\hline
\end{tabular}

Note: monomer (isoprene) concentration is $4.66 \mathrm{~mol} / 1$ 


\section{Conclusions}

Thus, the determination of the orders of polymerization reactions of isoprene in EA, in which both monomer and oligomer are dissolved, that is in the homogeneous system, showed the presence of specific features of polymerization with HP as initiator. While the reaction of termination is a typical process of recombination of macroradicals ( 0.5 order), an order by monomer (1.5) deviates from 1, characteristic for ideal polymerization, in spite of homogeneity of the polymerization system. Based on these facts, we consider that initiation takes place through decomposition of the monomer-initiator complex.

\section{References}

[1] Get'manchuk Yu. and Bratychak M.: Khimiya Vysokomolekulyarnyh Spoluk. NU "Lvivska politekhnika", Lviv 2008.

[2] Moad G. and Solomon D.: The Chemistry of Radical Polymerization. Elsevier 2006.

[3] Kabanov V., Zubov V. and Semchikov Yu.: KompleksnoRadikalnaya Polymerizacia. Khimiya, Moskwa 1987.

[4] Spirin Yu.: Reakcii Polymerizacii. Naukova dumka, Kyiv 1977.

[5] Oudian G.: Osnovy Khimii Polimerov. Mir, Moskwa 1974.

[6] Valuev V., Dmitrieva T., Shlyahter R. et al.: Vysokomol. Soed. A, 1982, 24, 1168.

[7] Grishchenko V., Boiko V., Svistova E. et al.: J. Appl. Polym. Sci., 1992, 46, 2081.

[8] Karaputadze T., Shumskiy V., Skurlatov Yu. and Kirsh Yu.: Vysokomol. Soed. B, 1982, 24, 305.

[9] Panarin E., Kalninsh C. and Azanova V.: Vysokomol. Soed. A, 2007, 49, 438 .
[10] Boiko V.: Vysokomol. Soed. A, 2005, 47, 2081.

[11] Grishchenko V., Pakirbaeva L., Tkach V. et al.: Ukr. Khim. Zh., 1987, 53, 768.

[12] Grishchenko V. and Spirin Yu.: Vysokomol. Soed. A, 1969, 11,980 .

[13] Spirin Yu., Grishchenko V. and Kochetova G.: Teor. Eksper. Khimiya, 1972, 8, 532.

[14] Boiko V.: Dopovidi Nats. Acad. Nauk Ukrainy, 2008, 2, 140. [15] Keil B. (ed.): Laboratornaya Tekhnika Organicheskoy Khimii. Mir, Moskwa 1966.

[16] Marcus Y.: Chem. Soc. Rev., 1993, 22, 409.

[17] Denisov E.: Zh. Phyz. Khimii, 1994, 68, 29.

[18] Pinazzi C., Legeay G. and Brosse J.: Makromol. Chem., 1975, 176, 2509.

\section{ПОЛІМЕРИЗАЦІЯІЗОПРЕНУ В ЕТИЛАЦЕТАТІ В ПРИСУТНОСТІ ПЕРОКСИДУ ВОДНЮ}

Анотація. Визначені порядки за мономером та ініціатором при полімеризації ізопрену в розчині етилацетату під дією пероксиду водню. Порядок за мономером дорівнює $1,49 \pm 0,03$, за інічіатором - 0,46 \pm 0,05. На відміну від полімеризації в розчині ізопропілового спирту, процес в етилачетаті протікає в гомогенному розчині. Значення порядку за мономером відрізняється від значення для ідеальної полімеризачії, вказуючи на специфічний механізм протікання полімеризачї̈ в такій системі, тоді як значення порядку за ініціатором вказує на квадратичний обрив макрорадикалів, характерний для ідеальної полімеризачії. Такі результати та дані літератури приводять до висновку, що ініціювання відбувається через розклад комплексу мономер-ініціатор.

Ключові слова: полімеризація, порядки реакції, ізопрен, вплив розчинника, пероксид водню, етилацетат, комплексоутворення. 